\title{
DISTRIBUTION AND THE SHERMAN ACT-THE EFFECTS OF GENERAL MOTORS, SCHWINN AND SEALY
}

\author{
LARRY L. WILLIAMS*
}

W HEN the Department of Justice recently took three distribution cases to the Supreme Court, it obviously hoped to broaden and clarify existing law as applied to the distributive process-White Motor Co. ${ }^{1}$ having failed to be a good vehicle. Now that General Motors Corp., ${ }^{2}$ Sealy, Inc., ${ }^{3}$ and Arnold, Schwinn of Co." have been decided it may be useful to examine these three cases to determine to what extent they have altered traditional antitrust law.

\section{General Motors Corp.}

In General Motors Corp. ${ }^{5}$ the government sought to outlaw an alleged agreement between General Motors and its Chevrolet dealers in the Los Angeles area whereby the dealers were forbidden from selling cars through discount houses. The charge was that the Chevrolet dealers in the area had conspired among themselves and with General Motors to suppress such sales in violation of section 1 of the Sherman Act. ${ }^{6}$ The trial court held that General Motors had a legal right under the "location clause" in its "Dealer Selling Agreements"-which restricts the dealer to a place of business approved by General Motors-to bar Chevrolet dealers from selling through discount houses. ${ }^{7}$ Judge Carr found that General Motors had merely enforced that contract right by unilateral action-without conspiring with the defendant dealer associations, and that the "location clause" was reasonably necessary to the preservation of General Motors' franchised-dealer system. ${ }^{8}$

* B.S., 1943, LL.B., 1948, Wake Forest College; Member, District of Columbia Bar.

1 White Motor Co. v. United States, 372 U.S. 253 (1963).

${ }^{2}$ United States v. General Motors Corp., 384 U.S. 127 (1966).

${ }^{8}$ United States v. Sealy, Inc., 87 Sup. Ct. 1847 (1967).

- United States v. Arnold, Schwinn \& Co., 87 Sup. Ct. 1856 (1967).

- United States v. General Motors Corp., 384 U.S. 127 (1966).

${ }^{6} 26$ Stat. 209-10 (1890), as amended, 15 U.S.C. $\$ 1$ (1964).

Inited States v. General Motors Corp., 234 F. Supp. 85, 88.89 (S.D. Cal. 1964).

${ }^{8}$ Ibid. 
On appeal to the Supreme Court the government was not satisfied to rest its case on a conspiracy theory but sought to have the court declare the "location clause" illegal. ${ }^{9}$ It was this attack that raised a new legal issue which could have had a significant impact on the automobile industry's method of doing business (all four automobile manufacturers use the location clause in their dealer contracts) and for franchising operations in general. The case, however, was decided as a "classic conspiracy" without regard to the "location clause" of the dealer contracts. ${ }^{10}$ Writing for a unanimous Court, Mr. Justice Fortas pointed to findings (l) that the dealer associations had initiated a letter writing campaign among their members to get General Motors to come to their aid against discount-house sales utilized by some of their members; (2) that General Motors personnel subsequently had discussed the matter with individual Los Angeles area dealers and elicited from each a promise not to do business with discounters; (3) that the associations had attempted to police compliance with those promises; and (4) that these collective efforts had induced several dealers to repurchase cars they had sold through discounters and to promise to refrain from further sales to them.11 On such findings, Mr. Justice Fortas saw "a classic conspiracy in restraint of trade: joint, collaborative action by dealers, the appellee associations, and General Motors to eliminate a class of competitors by terminating business dealings between them and a minority of Chevrolet dealers and to deprive franchised dealers of their freedom to deal through discounters if they so choose."12 $\mathrm{He}$ concluded that: "Elimination, by joint collaborative action, of discounters from access to the market is a per se violation of the Act."13 As a result no new Sherman Act law was developed, and the franchising industries were left where they were before the case was decided.14 However, the facts of General Motors Corp. and those in United States v. Parke, Davis \& Co. ${ }^{15}$ are such that a manu-

- 384 U.S. at 139.

${ }^{10} \mathrm{Id}$. at 140 . Mr. Justice Harlan in a concurring opinion called attention to the absence of anything in the majority opinion to prevent General Motors from enforcing the sales-location clause by unilateral action. Id. at 149.

11 Id. at $140-41$.

${ }^{12} I d$. at 140 .

${ }^{13} I d$. at 145 .

1* See Klor's, Inc. v. Broadway-Hale Stores, Inc., 359 U.S. 207 (1959).

28362 U.S. 29 (1960). 
facturer must be extremely circumspect in its actions if they are to be construed as truly unilateral.

\section{Arnold, Schwinn \& Co.}

What the government tried and failed to obtain in White Motor Co. ${ }^{16}$ and General Motors Corp. ${ }^{17}$ it acquired in Arnold, Schwinn \& Co. ${ }^{18}$ without trying. In Arnold, Schwinn of Co., the government sought a rule of reason decision but instead the Court held that

once the manufacturer has parted with title and risk, he has parted with dominion over the product, and his efforts thereafter to restrict territory or persons to whom the product may be transferred -whether by explicit agreement or by silent confirmation or understanding with his vendee-is a per se violation of $\S 1$ of the Sherman Act. ${ }^{19}$

By so holding the majority of the Court, in the words of Mr. Justice Stewart "reaches out to adopt a potent per se rule" justified by "no previous antitrust decision of this Court. Instead, it completely repudiates the only case in point, White Motor."20 While the Supreme Court had previously condemned as violative of the Sherman Act a manufacturer's requirement that his wholesalers sell only to retailers who hold licenses from the manufacturer, these restrictive distribution practices were ancillary to a price-fixing scheme and no determination had previously been made that they would be invalid independent of such a scheme. ${ }^{21}$

It is, of course, too early to tell what the impact will be of the per se invalidation of the determination by a manufacturer of persons to whom and places at which its products may be resold once con-

\footnotetext{
${ }^{10}$ White Motor Co. v. United States, 372 U.S. 253, 261 (1963).

17 United States v. General Motors Corp., 384 U.S. 127 (1966). The Court in Arnold, Schwinn \& Co. seems to foreclose General Motors from restricting its dealers from transacting sales with discounters, as sought by the government, but not granted by the Court in the General Motors Corp. case.

${ }^{18}$ United States v. Arnold, Schwinn \& Co., 87 Sup. Ct. 1856 (1967). While the Court did not consider whether a patentee has any greater rights, it suggested that United States v. Gencral Electric Co., 272 U.S. 476 (1926), be compared with United States v. New Wrinkle, Inc., 342 U.S. 371 (1952); United States v. Line Material Co., 333 U.S. 287 (1948); and United States v. Masonite Corp., 316 U.S. 265 (1942). These latter cases do not give much comfort to the patentee who wishes to impose area and customer restrictions on a licensee. By directing attention to these cases, it appears that the Court is saying that it is prepared to limit patentees the same as others. 1087 Sup. Ct. at 1867 .

20 Id. at 1870 .

21 White Motor Co. v. United States, 372 U.S. 253, 260 (1963); United States v. Bausch \& Lomb Optical Co., 321 U.S. 707, 721, 723-24 (1944).
} 
trol over them is relinquished. Mr. Justice Stewart, quoting from Mr. Justice Douglas' separate opinion in Standard Oil Co. v. United States, 22 foresees "suppliers [forced] to abandon franchising and integrate forward to the detriment of small business" and that "the small independent businessman will be supplanted by clerks."23 While independent service station operators may not be much more than clerks today, the Standard Oil Co. case has not led to forward integration by the oil industry, as predicted by Mr. Justice Douglas. ${ }^{24}$ Other types of independent businesses operating in the vast distribution industry may also be able to survive Schwinn. The agency and consignment method of distribution which was the heart of Schwinn's marketing system (accounting for $75 \%$ of the distribution of Schwinn's products) was held valid by the Supreme Court. ${ }^{25}$ Also, the Court pointed out that: "a manufacturer of a product, other and equivalent brands of which are readily available in the market, may select his customers, and for this purpose he may 'franchise' certain dealers to whom, alone, he will sell his goods."26 Although many manufacturers may turn to the agency and consignment marketing system, hundreds of manufacturers have for years been successfully operating under antitrust decrees forbidding precisely the same type of product control held per se illegal in Arnold, Schwinn \& Co. Injunctive provisions of this type have long been standard in Department of Justice consent and litigated decrees.

As previously noted the Court upheld the validity of the heart of Schwinn's distribution system-the consignment, agency or socalled "Schwinn-Plan"-representing $75 \%$ of the products it distributed. The Court said that after looking at the market as a whole, it could not "conclude that Schwinn's franchising of retailers and its confinement of retail sales to them-so long as it retains all indicia of ownership, including title, dominion, and risk, and so long as the dealings in question are indistinguishable in function from agents or salesmen-constitute an 'unreasonable' restraint of trade." 27 The

22337 U.S. 293, 321 (1949).

2887 Sup. Ct. at 1870 .

${ }^{24}$ The Federal Trade Commission Report on Anticompetitive Practices In The Marketing of Gasoline, ATRR No. 312, July 4, 1967.

${ }^{2 x} 87$ Sup. Ct. at I866.

${ }^{20}$ Id. at 1864 .

${ }^{27}$ Id. at 1866. The Court said it deemed critical the following facts: (1) the availabiilty of other competitive bicycles to distributors and retailers which are reasonably interchangeable with Schwinn products; (2) that Schwinn distributors and retailers 
Court explained that it was rejecting a per se rule approach to the consignment or agency system of distribution because such a "rule might severely hamper smaller enterprises resorting to reasonable methods of meeting the competition of giants and of merchandising through independent dealers, and it might sharply accelerate the trend towards vertical integration of the distribution process." 28 But the Court went on to warn that "to allow this freedom [to restrict the dealers] where the manufacturer has parted with dominion over the goods-the usual market situation-would violate the ancient rule against restraints on alienation and open the door to exclusivity of outlets and limitation of territory further than prudence permits."20

The justifications advanced for the restrictions upheld in Arnold, Schwinn \& Co. fall short of those suggested in White Motor Co..30 Schwinn was not a failing company. It was not a small company trying to break into or stay in a market nor a company marketing a new and risky product. Instead, it was the nation's leading bicycle producer. What appears to have moved the Court is the fact that Schwinn and other domestic bicycle manufacturers were competing against so-called mass merchandisers. The Court apparently believed that Schwinn's distribution restrictions were necessary to protect it against these large aggressive competitors. ${ }^{31}$

Thus, Arnold, Schwinn \& Co. seems to leave open the right of some manufacturers to impose some restrictions on the resale of their products, provided that they can show a business necessity to compete with larger competitors; that an agency or consignment plan is utilized so that dominion is retained over the products; and that the scheme is not part of a plan to fix, maintain or stabilize resale prices. However, these limitations create a narrow path for those who desire to impose resale restrictions on their dealers even under

handle other brands of bicycles as well as Schwinn's; (3) the vertical restraints at time of decision were not intermixed with price fixing; and (4) the findings of the trial court that competition made necessary the challenged program; and that its net effect is to preserve and not to damage competition in the bicycle market. Id. at 186667. The District Court had found that Schwinn adopted its agency or consignment plan in a competitive situation dominated by mass merchandisers such as Sears which had access to large scale advertising and promotion, choice retail outlets both owned and franchised, and adequate sources of supply. Id. at 1860.

${ }^{28} \mathrm{Id}$. at 1866.

29 Ibid.

so White Motor Co. v. United States, 372 U.S. 253 (1963).

s1 See 87 Sup. Ct. at 1864 . 
a consignment or agency arrangement. And, of course, if the territorial or dealer restrictions are accompanied by price fixing the result would be a per se violation of the Sherman Act. ${ }^{32}$

\section{SEALY, ING.}

The government prevailed in Sealy, Inc..$^{33}$ but as in Arnold, Schwinn \& $\mathrm{Co}^{34}$ it did not get the ruling it was seeking. Instead of creating new law, Sealy, Inc. casts a degree of doubt on what had heretofore seemed to be a clear principle of antitrust law-that horizontal territorial allocations are illegal per se under the Sherman Act.

Sealy, Inc., is owned and controlled by approximately 30 bedding manufacturers, each of which is licensed by Sealy to manufacture and sell bedding under Sealy's trademarks in mutually exclusive territories. The issue presented to the Court was whether this allocation of territories among the manufacturers violates section 1 of the Sherman Act. ${ }^{35}$ The government, relying on White Motor Co. ${ }^{36}$ and a long line of cases, contended that the arrangement was a horizontal case where competitors had agreed to divide markets-a per se violation of the Sherman Act. ${ }^{37}$ The Supreme Court agreed that the "territorial arrangements must be regarded as the creature of horizontal action by the licensees," viewing Sealy, Inc. as "an instrumentality of the licensees for purposes of the horizontal territorial allocation." 38 However, the Court did not condemn the arrangements as per se violative of the Sherman Act. Instead, it looked back to the fact that the arrangements for territorial limitations were part of a price-fixing scheme (which had been enjoined by the District Court and not appealed from) and condemned the arrangements as part of " 'an aggregation of trade restraints' including unlawful price fixing and policing.... Within settled doctrine, they are unlawful under $\S 1$ of the Sherman Act without the necessity for an inquiry in each particular case as to their business or

${ }^{33}$ Id. at 1862; United States v. Sealey, Inc., 87 Sup. Ct. 1847 (1967); Simpson v. Union Oil Co., 377 U.S. 13 (1964); United States v. Bausch \& Lomb Optical Co., 321 U.S. 707 (1944).

33 United States v. Sealy, Inc., supra note 32.

st United States v. Arnold, Schwinn \& Co., 87 Sup. Ct. 1856 (1967).

s5 26 Stat. 209-10 (1890), as amended, 15 U.S.C. $\$ 1$ (1964).

${ }^{30}$ White Motor Co. v. United States, 372 U.S. 253 (1963).

${ }^{37}$ Brief for the United States, pp. 7-8, United States v. Sealy, Inc., 87 Sup. Ct. 1847 (1967).

${ }^{88} 87$ Sup. Ct. at 1851. 
economic justification, their impact in the marketplace, or their reasonableness."39

What is puzzling about Sealy, Inc. is why the Court did not condemn the horizontal division of territories as illegal per se instead of relying on price-fixing to find an "aggregation of trade restraints," of the type found unlawful in Timkin Roller Bearing Co. ${ }^{40}$ As recently as White Motor Co., ${ }^{41}$ the Court, although it refrained from deciding whether a vertical arrangement by which a manufacturer restricted the territory of his dealers was per se illegal, flatly stated that: "if competitors agree to divide markets, they run afoul of the antitrust laws."42 In Northern Pac. Ry.,33 the Court had cited "division of markets" as one of several practices that are illegal per se. Furthermore, the Court in Sealy, Inc. seems to be saying what it has asserted over and over again-when not actually necessary to decide a case-that market division among competitors is illegal per se. Thus, in a footnote the Court quotes from Mr. Justice Harlan's concurring opinion in General Motors Corp. ${ }^{44}$ that: "Although Parke Davis related to alleged price-fixing, I have been unable to discern any tenable reason for differentiating it from a case involving, as here, alleged boycotting." "45 Then adds the Court: " The same conclusion would seem to apply with respect to an alleged market division, which, like price-fixing, group boycotts, and tying arrangements, has been held to be a per se violation of the Sherman Act. . . " "46

The only clue for the failure of the Court to apply a per se rule to a pure horizontal market division case is the argument of reasonableness. It was suggested to the Court that a number of small grocers might allocate territory among themselves on an exclusive basis as incident to the use of a common name and common advertisements, and that this type of an arrangement would be in the

\footnotetext{
${ }^{39} I d$. at 1852-53.

${ }^{10}$ Timken Roller Bearing Co. v. United States, 341 U.S. 593 (1951).

$₫ 1$ White Motor Co. v. United States, 372 U.S. 253 (1963).

13 Id. at 259.

${ }^{4}$ In Northern Pac. Ry. v. United States, 356 U.S. I, 5 (1958), the Court said: "... there are certain agreements or practices which because of their pernicious effect on competition and lack of any redeeming virtue are conclusively presumed to be unreasonable and therefore illegal without elaborate inquiry as to the precise harm they have caused or the business excuse for their use."

$\$$ United States v. General Motors Corp., 384 U.S. 127, 148.49 (1966).

1587 Sup. Ct. at $1852-53$ n.5.

to Ibid.
} 
interest of competition. Although the Court replied that it would leave this question open for decision if and when presented, ${ }^{47}$ it proceeds in a footnote to compare this type of situation to the reasonable tie-in circumstances in Northern Pac. Ry.: "As a simple example, if one of a dozen food stores in a community were to refuse to sell flour unless the buyer also took sugar, it would hardly tend to restrain competition in sugar if its competitors were ready and able to sell flour by itself." 48 Thus, the Court seems to be saying that there may be some market division situations less restrictive than in Sealy, Inc. that are not per se illegal; but it will tax the ingenuity of lawyers and businessmen to come up with a market allocation plan that will be reasonable. A division of markets creates a greater restraint on competition than does price-fixing, which is without question unlawful per se. While price-fixing eliminates one form of competition, an agreement of competitors to divide markets eliminates all competition between them.

\section{CONCLUSION}

Beginning with White Motor Co. ${ }^{49}$ and continuing with General Motors Corp., ${ }^{50}$ the government sought a rule of law which would prevent a manufacturer from limiting the area and the persons to whom its dealers could resell its products. The Court declined in both cases to hold such vertical restraint unlawful per se. In White Motor Co. it declined on the ground that it wanted to know more of the reasons for such restrictions than were available on a summary judgment record. In General Motors Corp. the government sought a ruling forbidding General Motors from unilaterally preventing its dealers from selling cars through discount houses, but the Court decided the case as "a classic conspiracy" between General Motors and its dealers to eliminate the discounters' market access.

In Arnold, Schwinn of Co. ${ }^{51}$ the government abandoned its per se approach and urged the Court to hold that it was an unreasonable restraint of trade for Schwinn to unilaterally require its dealers to limit the area or persons to whom they could resell Schwinn products. Instead of so holding, the Supreme Court for the first time

"7 Id. at 1852 .

${ }^{48}$ Id. at 1852 n.4.

${ }^{10}$ White Motor Co. v. United States, 372 U.S. 253 (1963).

${ }^{60}$ United States v. General Motors Corp., 384 U.S. 127 (1966).

-1 United States v. Arnold, Schwinn \& Co.s 87 Sup. Ct. 1856 (1967). 
adopted a per se approach and outlawed such activity where the manufacturer has parted with dominion over its products. However, even though Schwinn used the consignment or agency method for distribution of over $75 \%$ of its products, the Court held that this technique of distribution control was reasonable, apparently because it was convinced that the company needed to exercise such controls in order to compete with mass merchandisers. Nevertheless, the holding appears to be a narrow one that can be readily distinguished on the facts.

The Court also had an opportunity in Sealy, Inc. ${ }^{22}$ to apply a per se approach to a horizontal restrictive distribution system. Yet, it refused to do so relying instead on established law that an "aggregation of trade restraints" that includes price-fixing violates the Sherman Act. In order to take this approach the Court had to look at the case as originally tried, since the price-fixing activities had been held to be illegal at trial and no appeal had been taken from that holding. ${ }^{53}$

Thus, after four distribution cases have been decided by the Supreme Court, new law has been established only with respect to vertical arrangements where dominion has passed. The Court's reasons for refusing to state flatly what it has long said in dictumthat territorial allocations between competitors are illegal per seare puzzling indeed. Nevertheless, the degree to which even small companies can utilize a consignment or agency plan to restrict the retail distribution of their products or join with competitors to limit the areas in which or the persons to whom products may be resold, appears to be small and subject to a heavy burden of economic justification.

62 United States v. Sealy, Inc., 87 Sup. Ct. 1847 (1967).

${ }^{63}$ Id. at 1849 . 